\title{
PENGARUH INFLALSI, NILAI TUKAR, BI RATE DAN \\ FINANCING TO DEPOSIT RATIO (FDR) TERHADAP \\ TABUNGAN MUDHARABAH PADA BANK UMUM \\ SYARIAH DAN UNIT USAHA SYARIAH \\ DI INDONESIA TAHUN 2014-2018
}

\author{
Diyah Ayu Wulansari, A.Saiful Aziz \\ Universitas Wahid Hasyim \\ diyahayuwulansari@gmail.com, jhonsaifulaziz@gmail.com
}

\begin{abstract}
This study aims to analyze the influence of Inflation, Exchange Rates, BI Rate and Financing to Deposit Ratio (FDR) on the amount of Mudharabah Savings in Islamic Commercial Banks and Sharia Business Units in Indonesia from January 2014 - December 2018. This study uses secondary data in the form of month data January 2014 to December 2018 sourced from data from Bank Indonesia and the Financial Services Authority using multiple linear regression analysis. This study uses SPSS version 16.0 and Microsoft Exel 2007. The results of the study show that the Exchange Rate, BI Rate, and Financing to Deposit Ratio partially have a significant effect on the amount of Mudharabah savings. While partial inflation has no significant effect on Mudharabah Savings. Simultaneously Inflation, Exchange Rate, BI Rate, and Financing to Deposit Ratio significantly influence Mudharabah Savings.
\end{abstract}

Keywords: Inflation, Exchange Rates, BI Rate, Financing to Deposit Ratio, and Mudharabah Savings.

\section{PENDAHULUAN}

Kegiatan ekonomi dalam pandangan Islam merupakan hal yang wajar dan merupakan tuntutan kehidupan. Bank sebagai lembaga keuangan adalah bagian dari faktor penggerak kegiatan perekonomian. Kegiatan-kegiatan lembaga sebagai penyedia dan penyalur dana akan menentukan baik tidaknya perekonomian suatu Negara. ${ }^{1}$ Di negara Indonesia terdapat dua jenis perbankan yang beroperasi yaitu perbankan syariah dan konvensional.

\footnotetext{
${ }^{1}$ Reswari, Yutista Agil \& Ahim Abdurahim, "Pengaruh Tingkat Suku Bunga, Jumlah Bagi Hasil, dan LQ 45 terhadap Simpanan Mudharabah pada Bank Syariah di Indonesia ”,dalam jurnal Akuntansi dan Investasi, Vol. 11 No.1, Januari 2010, hal: 31.
} 
Dukungan terhadap pengembangan perbankan syariah juga diperlihatkan dengan adanya "dual banking sistem" berdasarkan peraturan OJK No.64/POJK.03.2016 menjeaskan tentang perubahan kegiatan bank konvensional menjadi bank syariah. Dimana bank konvensional diperkenankan untuk membuka Unit Usaha Syariah (UUS). ${ }^{2}$

Pertumbuhan dan perkembangan bank, baik dari konvensional maupun syariah bisa dilihat dari banyaknya jaringan kantor, asset, banyaknya produk-produk yang ditawarkan, dan banyaknya Dana Pihak Ketiga (DPK) yang dihimpun dari masyarakat. Ini berarti sebagian modal bank berasal dari masyarakat, lembaga keuangan lain, dan pinjaman likuiditas dari bank central. $^{3}$

Pertumbuhan DPK sangat penting karena dana tersebut akan disalurkan oleh bank kepada calon nasabah pembiayaan untuk mengembangkan ekonomi masyarakat, sehingga dapat mengembangkan sektor rill. ${ }^{4}$ Besarnya DPK menggambarkan tingkat kepercayaan masyarakat terhadap bank syariah. Banksyariah diharapkan menjadi solusi bagi umat manusia untuk menjalankan bisnis yang terbebas dari praktek ribawi sehingga dalam kegiatan operasionalnya bank syariah menggunakan prinsip utama yaitu bagi hasil. ${ }^{5}$

Diantara produk perbankan yang menggunakan prinsip bagi hasil dalam penghimpunan dana adalah tabungan Mudharabah. Tabungan Mudharabah sendiri adalah tabungan/ simpanan nasabah yang diperbolehkan untuk dikelola kembali oleh perbankan dengan tujuan untuk memperoleh keuntungan bersama yang keuntungannya akan dibagi sesuai kesepakatan bersama. ${ }^{6}$ Dalam menjalankan operasionalnya terdapat beberapa

\footnotetext{
2 Rasyidin, Didin. "Financing to Deposit Ratio (FDR) Sebagai Salah Satu Penilaian Kesehatan Bank Umum Syariah” Jurunal Ekonomi Keuangan dan Bisnis Islam, Voll. 7 No. 1, Juni 2013, hal $22-23$.

${ }^{3}$ Affandi, Faisal. “Analisis Pengaruh Tingkat Inflasi, Nilai Tukar, BI Rate, dan Suku Bunga Bank Konvensional Terhadap Margin Bagi Hasil Deposito Mudharabah Perbankan Syariah Periode 2010-2015", Jurusan Ekonomi Islam, Fakultas Ekonomi UIN-SU, Sumatra.2016, hal $50-51$.

${ }^{4}$ Roichan Moch dan Siti Suharyanti, "Determinan Tabungan Mudharabah Di Indonesia", jurnal ekonomi dan bisnis, Fakultas Ekonomi, UIN Syarif Hidayatullah, Jakarta 2013, hal : $149-150$.

5 M. Taufiq dan Batista Sufa, “ Pengaruh Inflasi, BI Rate Dan KURS Terhadap Indeks Harga Saham Gabungan”, Jurnal Ekonomi, 2016, hal 04.

${ }^{6}$ Rudiansyah, Afif, "Pengaruh Inflasi, BI Rate, PDB, dan Nilai Tukar Rupiah Terhadap Simpanan Mudharabah Pada Bank Syariah Di Indonesia”, Jurnal Ekonomi, UN Surabaya, Voll. 2 No.2, Surabaya, April 2014, hal : 308.
} 
faktor yang mempengaruhi keputusan nasabah untuk memilih jasa tabungan mudharaba baik dai internal maupun eksternal. ${ }^{7}$ Faktor internal yaitu Financing to Deposit Ratio yang merupakan rasio perbandiangan antara dana yang dikeluarkan untuk pembiayaan dengan dana pihak ketiga yang berhasil dihimpun dari nasabah. ${ }^{8}$

Selain itu terdapat faktor eksternal seperti inflasi, nilai tukar, dan BI Rate dimana inflasi yaitu jika harga terus menerus meningkat akan menimbulkan dampak buruk kepada individu, masyarakat, para kreditor, dan penabung. ${ }^{9}$ Nilai tukar sebagai salah satu faktor eksternal yang merupakan pembanding antara nilai mata uang dalam negeri dengan mata uang asing. BI Rate yang merupakan suku bunga kebijakan bank Indonesia yang menjadi acuan suku bunga di pasar uang, seperti suku bunga deposito, suku bunga Pasar Uang Antar Bank (PUAB) dan suku bunga kredit. ${ }^{10}$

Dalam kegiatannya tinggi rendahnya suku bunga tentunya akan berpengaruh kepada para nasabah dalam memilih produk perbankan mana yang menguntungkan dalam penghimpunan dana. Berdasarkan uraian diatas, tujuan yang ingin dicapai dari penelitian ini adalah mengetahui pengaruh inflasi, nilai tukar, BI Rate, dan Financing to Deposit Ratio (FDR) Terhadap Tabungan Mudharabah pada Bank Umum Syariah dan Unit Usaha Syariah di Indonesia Tahun 2014 -2018.

\section{KAJIAN TEORI}

\section{Tabungan Mudharabah}

Menurut Kasmir (2008) simpanan pada bank syariah dengan prinsip Mudharabah berarti penyimpan bertindak sebagai shahibul maal (pemilik modal) dan bank sebagai mudharib (pengelola). Dana tersebut digunakan bank untuk melakukan murabahah atau ijarah. Dapat pula dana

\footnotetext{
${ }^{7}$ Suharyanti, ST. “Analisis Pengaruh Nisbah Bagi Hasil, Inflasi, Pendapatan Nasional/PDB, dan SWBI Terhadap Tabungan Mudharabah Pada Perbankan Syariah Di Indonesia”. Jurnal Ilmu Ekonomi dan Studi Pembangunan, Fakultas Ekonomi dan Bisnis UIN Syarif Hidayatullah, (Jakarta: UIN JKT, 2010), 11.

8 Ahmad Roziq dan Rinanda Diptyanti. “ Variabel Penentu Dalam Keputusan Memilih Tabungan Mudharabah Pada Bank Syariah Mandiri Cabang Jember”. Jurnal Ekonomi, Voll. 7 No.1, Jember.2013.

9 Sudarsono, Heri.2003. Bank Dan Lembaga Keuangan Syariah, (Yogyakarta, Ekonidia, 2003), 39-40.

${ }^{10}$ Aldrin dan Susi Suhendra. Analisis Pengaruh Nilai Kurs, Tingkat Inflasi, dan Tingkkat Suku Bunga Terhadap Dana Pihak Ketiga Pada Bank Devisa Di Indonesia Periode 2003 2008. Jurnal Ekonomi, Universitas Gunadarma, Desember 2008, hal : 02 - 03.
} 
tersebut digunakan untuk melakukan Mudharabah yang kedua. Hasil usaha ini akan dibagi hasilkan berdasarkan nisbah (persentase bagi hasil) yang disepakati. Rukun Mudharabah terpenuhi sempurna (ada mudhahrib atau pengelola, ada pemilik dana, ada usaha yang akan dibagihasilkan, ada nisbah, dan ada ijab qabul). Prinsip Mudharabah ini diaplikasikan pada produk tabungan berjangka dan deposito berjangka. ${ }^{11}$

\section{Inflasi}

Inflasi merupakan suatu nilai dimana tingkat harga barang dan jasa secara umum mengalami kenaikan. Kenaikan harga dari satu atau dua barang saja tidak disebut inflasi kecuali bila kenaikan tersebut meluas kepada atau mengakibatkan kenaikan harga sebagian harga barangbarang yang lain. Dan kebalikan dari inflasi yaitu deflasi. Hal ini tidak berarti bahwa harga berbagai macam barang itu naik dengan presentase yang sama. ${ }^{12}$ Mungkin terjadi kenaikan tetapi dengan presentase yang berbeda-beda, yang terpenting adalah terdapat kenaikan harga umum barang secara terus-menerus pada suatu periode tertentu. Kenaikan yang terjadi hanya sekali saja walaupun dengan presentase kenaikan yang tinggi bukan merupakan inflasi. ${ }^{13}$

\section{Nilai Tukar (Kurs)}

Menurut Faisal Affandi (2016) Nilai tukar merepresentasikan tingkat harga pertukaran dari satu mata uang ke mata uang lainnya dan digunakan dalam berbagai transaksi, antara lain perdagangan internasional, aliran jangka pendek antar negara yang melewati batasbatas geografis atau batas-batas hukum. Nilai tukar rupiah adalah nilai yang menunjukan jumlah mata uang dalam negeri yang diperlukan untuk mendapat satu unit mata uang asing. ${ }^{14}$

\footnotetext{
${ }_{11}^{11}$ Ascarya. 2007. Akad dan Produk Bank Syariah. Jakarta. PT. Raja Grafindo Persada.

12 Suryani, "Sistem Perbankan Islam di Indonesia", Jurnal Ekonomi Islam, Voll. 3 No.1, STAIN Malikussaleh, Lhokseumawe, Juli.2012, hal : 120.

13 Asgnari Imam, "Pengaruh Kondisi Ekonomi Makro dan Karakteristik Bank Terhadap Efisiensi Industri Perbankan Syariah di Indonesia", dalam jurnal Ekonomi Pembangunan, Voll. 11 No.2, Desember 2013, hal 91.

${ }^{14}$ Mauliawati, Lidya Nisa dan Tatik Maryati. 2015. "Analisis Pengaruh Inflasi, Kurs, Suku Bunga, dan Bagi Hasil Terhadap Deposito Pada PT. Bank Syariah Mandiri 2007-2012 ”, hal: 736
} 


\section{Suku Bunga (BI Rate)}

BI rate menurut Bank Indonesia adalah suku bunga kebijakan yang mencerminkan sikap atau stance kebijakan moneter yang ditetapkan oleh Bank Indonesia dan diumumkan kepada publik. BI rate merupakan indikasi suku bunga jangka pendek yang diinginkan Bank Indonesia dalam upaya mencapai target inflasi. ${ }^{15} \mathrm{BI}$ rate digunakan sebagai acuan dalam operasi moneter untuk mengarahkan agar suku bunga SBI 1 bulan hasil lelang operasi pasar terbuka berada disekitar BI rate. Selanjutnya suku bunga BI diharapkan mempengaruhi PUAB, suku bunga pinjaman, dan suku bunga lainnya dalam jangka panjang. ${ }^{16}$

\section{Financing to Deposit Ratio (FDR)}

FDR adalah rasio antara seluruh jumlah kredit yang diberikan bank dengan dana yang diterima oleh bank. Financing to Deposit Ratio menggambarkakemampuan perbankan membayar kembali penarikan yang dilakukan nasabah deposan dengan mengandalkan kredit yang diberikan sebagai sumber likuiditasnya.Untuk menhitung nilai dari Financing to Deposit Ratio, dapat menggunakan suatu persamaan sebagaimana yang telah ditetapkan oleh Bank Indonesia dalam Surat Edaran Bank Indonesia No.6 /23/ DPNP Tanggal 31 Mei 2004. ${ }^{17}$

\section{METODE}

\section{Jenis Penelitian, Populasi dan Sampel}

Jenis penelitian yang digunakan adalah penelitian kuantitatif dimana data yang di peroleh bersumber dari situs resmi dan di publikasikan. Metode yang digunakan adalah historis atau menganalisa sebuah keadaan yang sudah lalu dan menganalisis hubungan antara variabel independen terhadap variabel dependen. Sedangkan populasi dan

${ }^{15}$ Utari, Herlina. "Pengaruh Inflasi, Kurs, Bi Rate Terhadap Nilai Aktiva Bersih (NAB) Reksadana Syariah di Indonesia Tahun 2010 - 2018”. Jurnal Ekonomi, Institut Agama Islam Negri Tulungagung, Tulungagung, Oktober 2017, hal : $61-64$.

${ }^{16}$ Boediono. 1987. Ekonomi Internasional. Bandung. CV. Bima Cipta, hal 161.

17 Dahlan Siamat. 2004. Manajemenn Lembaga Keuangan . Edisi Keempat. Jakarta: Lembaga Penerbit Fakultas Univesitas Indonesia, hal 87. 
sampel yang digunakan adalah seluruh Bank Umum Syariah dan Unit Usaha Syariah di Indonesia. ${ }^{18}$

\section{Sumber dan Teknik Pengumpulan Data}

Data yang digunakan dalam penelitian ini adalah data sekunder, yang berarti perolehan data dari dokumentasi, dengan laporan yang sudah dipublikasikan atau arsip-arsip resmi. Data sekunder dalam penelitian ini bersifat time series, yang berati data yang digunakan adalah bulanan atau pengumpulan data dari waktu ke waktu untuk melihat perkembangan. Perolehan data bersumber dari website Otoritas Jasa Keuangan ( OJK ) dan website Bank Indonesia (BI) dari Januari 2014 hingga Desember 2018 dengan data bulanan. ${ }^{19}$

\section{Metode Analisis}

Metode analisis yang digunakan yaitu uji asumsi klasik yang terdiri dari uji normalitas, uji multikolinieritas, uji heterokedastisitas, dan uji autokorelasi. Selain itu menggunakan analisis regresi linier berganda dan uji signifikasi yang terdiri dari uji $\mathrm{T}$, uji F, dan determinasi $\left(\mathrm{R}^{2}\right)$.

\section{HASIL DAN PEMBAHASAN}

\section{Uji Asumsi Klasik}

\section{One-Sample Kolmogorov-Smirnov Test}

\begin{tabular}{|ll|r|}
\hline & & Unstandardized Residual \\
\hline $\mathrm{N}$ & & 60 \\
Normal Parameters ${ }^{\mathrm{a}}$ & Mean & .0000000 \\
& Std. Deviation & .06152209 \\
Most Extreme & Absolute & .113 \\
Differences & Positive & .113 \\
& Negative & -.082 \\
Kolmogorov-Smirnov Z & & .874 \\
Asymp. Sig. (2-tailed) & & .429 \\
\hline
\end{tabular}

a. Test distribution is Normal.

\footnotetext{
${ }^{18}$ Fitri, Maltuf. "Peran Dana Pihak Ketiga Dalam Kinerja Lembaga Pembiayaan Syariah Dan Faktor-Faktor Yang Mempengaruhinya”, Jurnal Ekonomi, UIN Walisongo, Voll. 7 No.1, Semarang. 2013, hal 75.

${ }^{19}$ Friska Julianti. " Pengaruh Inflasi, KURS, BI Rate Terhadap Tabungan Mudharabah Pada Perbankan Syariah”, Jurusan Ekonomi , Universitas Syarif Hidayatullah, Jakarta. 2013, hal 17.
} 
Berdasarkan tabel di atas menggunakan Kolmogornov Smirnov, dengan melihat Asymp Sig. (2-tailed) jika nilainya lebih dari 0,05 maka data dikatakan normal. Hasil dari uji Kolmogornov Smirnov terlihat bahwa nilai Asymp. Sig. (2-tailed) sebesar 0,429>0,05 (Sig. $>\alpha$ ). Hal ini berati nilai residual terstandarisasi dikatakan menyebar secara normal.

\section{Uji Multikolinieritas}

Coefficients $^{\mathrm{a}}$

\begin{tabular}{|l|r|c|}
\hline \multirow{2}{*}{\multicolumn{1}{|c|}{ Model }} & \multicolumn{2}{|c|}{ Collinearity Statistics } \\
\cline { 2 - 3 } & Tolerance & \multicolumn{1}{c|}{ VIF } \\
\hline (Constant) & & \\
& & \\
INFLASI_X1 & .398 & 2.510 \\
KURS_X2 & .225 & 4.443 \\
BIRATE_X3 & .185 & 5.405 \\
FDR_X4 & .106 & 9.458 \\
\hline
\end{tabular}

a. Dependent Variable: LN_TM

Uji multikolinieritas dengan melihat nilai Tolerance dan VIF. Hasil penelitian Tolerance menunjukkan bahwa masing-masing variabel lebih besar dari 0,1 dan VIF dari masing-masing variabel kurang dari 10. Sehingga dapat diketahui data tidak terkena Multikolinieritas. ${ }^{20}$

\section{Uji Heterokedastisitas}

Uji heterokedastisitas dalam penelitian ini menggunakan grafik scatterplot maka diperoleh hasil sebagai berikut :

$$
\text { Scatterplot }
$$

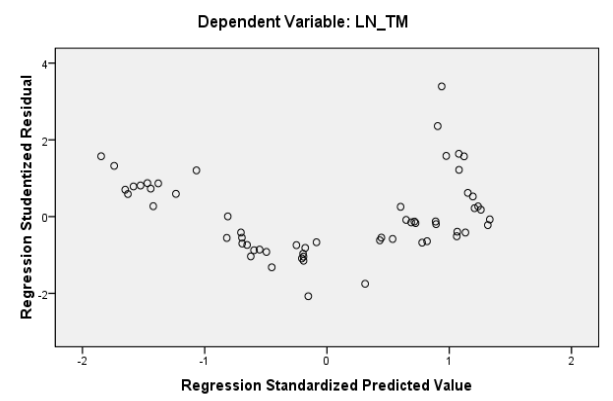

${ }^{20}$ Harahap, Darwis. “Determinan Dana Pihak Ketiga Bank Syariah Indonesia”, Jurnal Ekonomi, IAIN Padangsidimpuan, Vol. 10 No.1, Sumatra Utara.2017, hal 18. 
$58\}\{$ Pengaruh Inflalsi, Nilai Tukar, BI Rate dan Financing to Deposit Ratio (FDR)

Dalam grafik scatterplot, hasil menunjukkan bahwa titik-titik tersebar secara acak diatas dan dibawah sumbu nol dan tidak membentuk pola tertentu, sehingga data tersebut tidak terkena gejala heterokedastisitas. $^{21}$

\section{Uji Autokorelasi}

Model Summary

\begin{tabular}{|l|r|r|r|r|r|}
\hline Model & R & R Square & $\begin{array}{c}\text { Adjusted R } \\
\text { Square }\end{array}$ & $\begin{array}{c}\text { Std. Error of } \\
\text { the Estimate }\end{array}$ & $\begin{array}{l}\text { Durbin- } \\
\text { Watson }\end{array}$ \\
\hline 1 & $.954^{\mathrm{a}}$ & .910 & .904 & .06372 & .274 \\
\hline
\end{tabular}

a. Predictors: (Constant), FDR_X4, INFLASI_X1, KURS_X2, BIRATE_X3

b. Dependent Variable: LN_TM

Uji autokorelasi dalam penelitian ini menggunakan DurbinWatson. Nilai DW jika angkanya berada diantara -2 sampai +2 maka data tidak terkena gejala autokorelasi. Hasil penelitian diperoleh angka 0,274. Bahwa angka tersebut berada dantara -2 sampai dengan +2 sehingga dapat dikatakan bahwa data tidak terdapat gejala autokorelasi.

\section{Analisis Regresi Linier Berganda}

Berdasarkan tabel diperoleh model persamaan sebagai berikut :

\section{Coefficients $^{\mathrm{a}}$}

\begin{tabular}{|l|r|r|r|r|r|}
\hline & \multicolumn{2}{|c|}{$\begin{array}{c}\text { Unstandardized } \\
\text { Coefficients }\end{array}$} & $\begin{array}{c}\text { Standardize } \\
\text { Coefficients }\end{array}$ & & \\
\cline { 2 - 4 } \multicolumn{1}{|c|}{ Model } & \multicolumn{1}{c|}{ B } & \multicolumn{1}{c|}{$\begin{array}{c}\text { Std. } \\
\text { Error }\end{array}$} & \multicolumn{1}{c|}{ Beta } & \multicolumn{1}{c|}{ T } & \multicolumn{1}{c|}{ Sig. } \\
\hline 1(Constant) & 25.682 & .501 & & 51.259 & .000 \\
INFLASI_X1 & -.008 & .008 & -.068 & -1.065 & .291 \\
KURS_X2 & 4.358 & .000 & .182 & 2.136 & .037 \\
BIRATE_X3 & -.058 & .014 & -.380 & -4.051 & .000 \\
FDR_X4 & -.012 & .004 & -.429 & -3.450 & .001 \\
\hline
\end{tabular}

a. Dependent Variable: LN_TM

\footnotetext{
${ }^{21}$ Kasmir. 2008. Bank dan Lembaga Keuangan Lainnya. Edisi Revisi 2008. Jakarta: PT. Raja Grafindo Persada, hal 78.
}

..::: Malia: Jurnal Ekonomi Islam, Volume 11 Nomor 1 Desember 2019 :::.. 
$\mathrm{L}_{-} \mathrm{TM}=25,682-0,008 \mathrm{X}_{1}+4,358 \mathrm{X}_{2}-0,058 \mathrm{X}_{3}-0,012 \mathrm{X}_{4}+\mathrm{e}$

Dari persamaan regresi tersebut maka dapat diinterpretasikan sebagai berikut:

a. Nilai konstan regresi sebesar 25,682. Menunjukkan bahwa apabila Inflasi, Kurs, BI Rate, dan Financing to Deposit Ratio (FDR) dengan kondisi konstan atau 0, maka Tabungan Mudharabahbernilai 25,682.

b. Koefisien Inflasi sebesar -0,008. Menunjukkan bahwa Infasi mempunyai pengaruh negatif terhadap Tabungan Mudharabah. Hal ini berati bahwa apabila Inflasi meningkat satu satuan maka Tabungan Mudharabah akan menurun sebesar -0,008 dengan asumsi semua variabel independen lain konstan.

c. Koefisien Nilai Tukar (kurs) sebesar 4,358. Menunjukkan bahwa Nilai Tukar mempunyai pengaruh positif terhadap Tabungan Mudharabah. Hal ini berati bahwa apabila Nilai Tukar meningkatsatu satuan maka Tabungan Mudharabah akan meningkat sebesar 4,358 dengan asumsi semua variabel independen lain konstan.

d. Koefisien BI Rate sebesar -0,058. Menunjukkan bahwa BI Rate mempunyai pengaruh negatif terhadap Tabungan Mudharabah. Hal ini berati bahwa apabila Nilai Tukar meningkat satu satuan maka Tabungan Mudharabah akan menurun sebesar -0,058 dengan asumsi semua variabel independen lain konstan.

e. Koefisien Financing to Deposit Ratio (FDR) sebesar -0,012. Menunjukkan bahwa FDR mempunyai pengaruh negatif terhadap Tabungan Mudharabah. Hal ini berati bahwa apabila FDR meningkat satu satuan maka Tabungan Mudharabah akan menurun sebesar 0,012 dengan asumsi semua variabel independen lain konstan.

\section{Uji Hipotesis}

\section{Pengujian Secara Parsial denan t-test}

Coefficients $^{\mathrm{a}}$

\begin{tabular}{|l|c|c|c|c|c|}
\hline \multirow{2}{*}{ Model } & \multicolumn{2}{|c|}{$\begin{array}{c}\text { Unstandardized } \\
\text { Coefficients }\end{array}$} & $\begin{array}{c}\text { Standardized } \\
\text { Coefficients }\end{array}$ & & \\
\cline { 2 - 5 } & B & $\begin{array}{c}\text { Std. } \\
\text { Error }\end{array}$ & Beta & $\mathrm{t}$ & Sig. \\
\hline 1 (Constant) & 25.682 & .501 & & 51.259 & .000 \\
\hline
\end{tabular}

..::: Malia: Jurnal Ekonomi Islam, Volume 11 Nomor 1 Desember 2019 :::.. 
$60\}\{$ Pengaruh Inflalsi, Nilai Tukar, BI Rate dan Financing to Deposit Ratio (FDR)

\begin{tabular}{l|r|r|r|r|r|} 
INFLASI_X1 & -.008 & .008 & -.068 & -1.065 & .291 \\
KURS_X2 & 4.358 & .000 & .182 & 2.136 & .037 \\
BIRATE_X3 & -.058 & .014 & -.380 & -4.051 & .000 \\
FDR_X4 & -.012 & .004 & -.429 & -3.450 & .001 \\
\hline
\end{tabular}

a. Dependent Variable: LN_TM

Hasil uji tersebut menunjukkan bahwa variabel inflasi memiliki nilai sig. $\alpha$ sebesar 0,291, maka 0,291 lebih dari $\alpha=0,05$ artinya variabel inflasi tidak berpengaruh signifikan terhadap tabungan Mudharabah. Variabel nilai tukar memiliki nilai sig adalah 0,037 , maka 0,37 kurang dari $\alpha=0,05$ artinya variabel nilai tukar berpengaruh signifikan terhadap tabungan Mudharabah. Variabel BI rate memiliki nilai sig. $\alpha$ sebesar 0,000, maka 0,000 kurang dari $\alpha=0,05$ artinya variabel $\mathrm{BI}$ rate berpengaruh signifikan terhadap tabungan Mudharabah.Variabel Financing too Deposit Ratio (FDR) memiliki nilai sig. $\alpha$ sebesar 0,001, maka 0,001 kurang dari $\alpha=0,05$ artinya variabel Financing to Deposit Ratio (FDR) berpengaruh signifikan terhadap tabungan Mudharabah.

\section{Secara simultan dengan $\mathrm{F}$ - test}

Hasil usji simultan variabel inflasi, nilai tukar, Bi rate, dan Financing to Deposit Ratio terhadap tabungan Mudharabah di gambarkan sebagai berikut:

ANOVA ${ }^{\mathbf{b}}$

\begin{tabular}{|l|r|r|r|r|r|}
\hline Model & $\begin{array}{c}\text { Sum of } \\
\text { Squares }\end{array}$ & Df & $\begin{array}{c}\text { Mean } \\
\text { Square }\end{array}$ & F & Sig. \\
\hline Regression & 2.266 & 4 & .566 & 139.511 & $.000^{\mathrm{a}}$ \\
Residual & .223 & 55 & .004 & & \\
Total & 2.489 & 59 & & & \\
\hline
\end{tabular}

a. Predictors: (Constant), FDR_X4, INFLASI_X1, KURS_X2, BIRATE_X3

b. Dependent Variable: LN_TM

Dalam penelitian ini menggunakan taraf signifikansi $(\alpha)$ sebesar 0,05 . Dari hasil perhitungan diperoleh nilai $F_{\text {hitung }}$ sebesar 139,511 dengan nilai sig sebesar 0,000. Selanjutnya dalam penelitian ini dengan membandingkan 
nilai $\mathrm{F}_{\text {tabel }}$ dan $\mathrm{F}_{\text {hitung. Nilai }} \mathrm{F}_{\text {tabel }}$ didapatkan dari $(\mathrm{k} ; \mathrm{n}-\mathrm{k})=(4 ; 60-4)=(4$; 56) sehingga diketahui Ftabel sebesar 2,53. Dalam penelitian ini $F_{\text {hitung }}>F_{\text {tabel }}$ dan nilai sig $0,000<0,05$, sehingga $\mathrm{H} 0$ ditolak dan $\mathrm{H} 1$ diterima. Artinya Inflasi, Kurs, BI Rate, dan Financing to Deposit Ratio secara bersama - sama berpengaruh signifikan terhadap Tabungan Mudharabah.

\section{Uji Koefisien Determinasi $\left(\mathbf{R}^{2}\right)$}

Hasil uji determinasi $\left(\mathrm{R}^{2}\right)$ didapat bahwa $R$ Square $\left(\mathrm{R}^{2}\right)$ sebesar 0,910. Hal ini menunjukan bahwa kontribusi Inflasi, Kurs, BI Rate, dan Financing to Deposit Ratio terhadap Tabungan Mudharabah pada Perbankan Syariah di Indonesia sebesar 0,910 atau 91\%. Dengan kata lain Tabungan Mudharabah pada Perbankan Syariah dapat dipengaruhi oleh Inflasi, Kurs, BI Rate, dan Financing to Deposit Ratio sebesar 91\% selanjutnya 9\% sisanya dipengaruhi oleh variabel lain diluar penelitian. ${ }^{22}$

\section{PEMBAHASAN}

1. Hasil penelitian menunjukkan bahwa inflasi tidak berpengaruh signifikan terhadap Tabungan Mudharabah, bahwa inflasi masih berada dalam batas normal dengan nilai dibawah $10 \%$. Sehingga dalam pengimpunan dana tabungann Mudharabah masih stabil dan lancar.

2. Hasil penelitian menunjukkan bahwa nilai tukar berpengaruh positif signifikan terhadap Tabungan Mudharabah, bahwa jika nilai tukar tinggi maka terjadi ketidakpastian kondisi ekonomi makro yang menyebabkan beralihnya para investor untuk berinvestasi di perbankansehingga meningkatkan tabungan Mudharabah. ${ }^{23}$

3. Hasil penelitian menunjukkan bahwa BI Rate berpengaruh negatif signifikan terhadap Tabungan Mudharabah, jika suku bunga BI meningkat akan menyebabkan naiknya bunga pada bank konvensional sehingga tabungan Mudharabah akan menurun karena beralihnya nasabah ke bank konvensional. ${ }^{24}$

\footnotetext{
${ }^{22}$ Lydia Rahmadhini dan Ade Sofyan. “Analisis Faktor-Faktor Yang Mempengaruhi Tingkat Bagi Hasil Simpanan Mudharabah Pada Bank Umum Syariah Di Indonesia Periode 2011 2015”. Jurnal Ekonomi dan Perbankan Syariah. UIN Syarif Hidayatullah, Voll.4 No.1, Jakarta, Juni 2014, hal 09.

${ }^{23}$ Lauda Huruniang dan Noven Suprayogi. “Variabel-Variabel Yang Mempengaruhi Tingkat Bagi Hasil Tabungan Mudharabah Pada Industri Perbankan Syariah Di Indonesia Periode 2011-2014". Jurnal Ekonomi dan Bisnis, Universitas Airlangga, Voll. 2 No.7, Juli.2015.

${ }^{24}$ Mahmudatus Sa'diyah dan Meuthiya Athifa Arifin, "Mudharabah Dalam Fiqih dan Perbankan Syariah", Voll. 1 No.2, Desember 2013, hal: 303 - 304.
} 
$62\}\{$ Pengaruh Inflalsi, Nilai Tukar, BI Rate dan Financing to Deposit Ratio (FDR)

4. Hasil penelitian menunjukkan bahwa Financing to Deposit Ratio (FDR) berpengaruh negatif signifikan terhadap Tabungan Mudharabah, bahwa jumlah tabungan Mudharabah lebih tinggi daripada pembiayaan yang dikeluarkan sehingga FDR menurun.

\section{KESIMPULAN}

Berdasarkan hasil penelitian dan pembahasan yang telah dipaparkan sebelumnya, maka dapat diambil kesimpulan:

1. Variabel Nilai Tukar secara parsial berpengaruh positif signifikan terhadap tabungan Mudharabah pada bank umum syariah dan unit usaha syariah di Indonesia.

2. Variabel BI Rate secara parsial berpengaruh negatigf signifikan terhadap tabungan Mudharabah pada bank umum syariah dan unit usaha syariah di Indonesia.

3. Variabel Financing to Deposit Ratio (FDR) secara parsial berpengaruh secara signifikan terhadap tabungan Mudharabah pada bank umum syariah dan unit usaha syariah di Indonesia

4. Variabel Inflasi secara parsial tidak berpengaruh secara signifikan terhadap tabungan Mudharabah pada bank umum syariah dan unit usaha syariah di Indonesia

5. Berdasarkan hasil uji secara simultan dengan nilai Fhitung 139,511 dan nilai sig. 0,000 menjelaskan bahwa inflasi, nilai tukar, BI Rate, dan Financing to Deposit Ratio secara bersama-sama berpengaruh signifikan terhadap tabungan Mudharabah.

6. Berdasarkan hasil uji determinasi variabel Inflasi, Kurs, BI Rate, dan Financing to Deposit Ratio secara bersama - sama berpengaruh signifikan terhadap tabungan Mudharabah pada Bank Umum Syariah dan Unit Usaha Syariah di Indonesia. Dengan kontribusi sebesar 91\% sedangkan 9\% sisanya dipengaruhi oleh variabel lain diluar penelitian.

\section{DAFTAR PUSTAKA}

Affandi, Faisal. “ Analisis Pengaruh Tingkat Inflasi, Nilai Tukar, BI Rate, dan Suku Bunga Bank Konvensional Terhadap Margin Bagi Hasil Deposito Mudharabah Perbankan Syariah Periode 2010-2015", Jurusan Ekonomi Islam, Fakultas Ekonomi UIN-SU, Sumatra. 2016. 
Ahmad Roziq dan Rinanda Diptyanti. “Variabel Penentu Dalam Keputusan Memilih Tabungan Mudharabah Pada Bank Syariah Mandiri Cabang Jember". Jurnal Ekonomi, Voll. 7 No.1, Jember.2013.

Aldrin dan Susi Suhendra. "Analisis Pengaruh Nilai Kurs, Tingkat Inflasi, dan Tingkkat Suku Bunga Terhadap Dana Pihak Ketiga Pada Bank Devisa Di Indonesia Periode 2003-2008”. Jurnal Ekonomi, Universitas Gunadarma, Desember 2008.

Ascarya. 2007. Akad dan Produk Bank Syariah. Jakarta. PT. Raja Grafindo Persada.

Asgnari Imam, “ Pengaruh Kondisi Ekonomi Makro dan Karakteristik Bank Terhadap Efisiensi Industri Perbankan Syariah di Indonesia”, dalam jurnal Ekonomi Pembangunan, Voll. 11 No.2, Desember 2013.

Boediono. 1987. Ekonomi Internasional. Bandung. CV. Bima Cipta, hal 161.

Dahlan Siamat. 2004. Manajemenn Lembaga Keuangan . Edisi Keempat. Jakarta: Lembaga Penerbit Fakultas Univesitas Indonesia.

Fitri, Maltuf. "Peran Dana Pihak Ketiga Dalam Kinerja Lembaga Pembiayaan Syariah Dan Faktor-Faktor Yang Mempengaruhinya", Jurnal Ekonomi, UIN Walisongo, Voll. 7 No.1, Semarang. 2013.

Friska Julianti. "Pengaruh Inflasi, KURS, BI Rate Terhadap Tabungan Mudharabah Pada Perbankan Syariah", Jurusan Ekonomi , Universitas Syarif Hidayatullah, Jakarta. 2013.

Harahap, Darwis. “ Determinan Dana Pihak Ketiga Bank Syariah Indonesia”, Jurnal Ekonomi, IAIN Padangsidimpuan, Vol. 10 No.1, Sumatra Utara.2017.

Kasmir. 2008. Bank dan Lembaga Keuangan Lainnya. Edisi Revisi 2008. Jakarta: PT. Raja Grafindo Persada.

Lauda Huruniang dan Noven Suprayogi. "Variabel-Variabel Yang Mempengaruhi Tingkat Bagi Hasil Tabungan Mudharabah Pada Industri Perbankan Syariah Di Indonesia Periode 2011-2014”. Jurnal Ekonomi dan Bisnis, Universitas Airlangga, Voll. 2 No.7.

Lydia Rahmadhini dan Ade Sofyan. "Analisis Faktor-Faktor Yang Mempengaruhi Tingkat Bagi Hasil Simpanan Mudharabah Pada Bank Umum Syariah Di Indonesia Periode 2011-2015”. Jurnal Ekonomi dan Perbankan Syariah. UIN Syarif Hidayatullah, Voll.4 No.1, Jakarta, Juni 2014.

Mahmudatus Sa'diyah dan Meuthiya Athifa Arifin, "Mudharabah Dalam Fiqih dan Perbankan Syariah", Voll. 1 No.2, Desember 2013.

..::: Malia: Jurnal Ekonomi Islam, Volume 11 Nomor 1 Desember 2019 :::.. 
$64\}\{$ Pengaruh Inflalsi, Nilai Tukar, BI Rate dan Financing to Deposit Ratio (FDR)

Mauliawati, Lidya Nisa dan Tatik Maryati. 2015. "Analisis Pengaruh Inflasi, Kurs, Suku Bunga, dan Bagi Hasil Terhadap Deposito Pada PT. Bank Syariah Mandiri 2007-2012".

M. Taufiq dan Batista Sufa, "Pengaruh Inflasi, BI Rate Dan KURS Terhadap Indeks Harga Saham Gabungan”, Jurnal Ekonomi, 2016.

Rasyidin, Didin. "Financing to Deposit Ratio (FDR) Sebagai Salah Satu Penilaian Kesehatan Bank Umum Syariah" Jurunal Ekonomi Keuangan dan Bisnis Islam, Voll. 7 No. 1, Juni 2013.

Reswari, Yutista Agil \& Ahim Abdurahim, "Pengaruh Tingkat Suku Bunga, Jumlah Bagi Hasil, dan LQ 45 terhadap Simpanan Mudharabah pada Bank Syariah di Indonesia ",dalam jurnal Akuntansi dan Investasi, Voll. 11 No.1, Januari 2010.

Roichan Moch dan Siti Suharyanti, "Determinan Tabungan Mudharabah Di Indonesia", jurnal ekonomi dan bisnis, Fakultas Ekonomi, UIN Syarif Hidayatullah, Jakarta 2013.

Rudiansyah, Afif, "Pengaruh Inflasi, BI Rate, PDB, dan Nilai Tukar Rupiah Terhadap Simpanan Mudharabah Pada Bank Syariah Di Indonesia”, Jurnal Ekonomi, UN Surabaya, Voll. 2 No.2, Surabaya, April 2014.

Sudarsono, Heri.2003. Bank Dan Lembaga Keuangan Syariah, Ekonidia, Yogyakarta.

Suharyanti, ST. "Analisis Pengaruh Nisbah Bagi Hasil, Inflasi, Pendapatan Nasional/PDB, dan SWBI Terhadap Tabungan Mudharabah Pada Perbankan Syariah Di Indonesia". Jurnal Ilmu Ekonomi dan Studi

Pembangunan, Fakultas Ekonomi dan Bisnis UIN Syarif Hidayatullah, Jakarta, 2010.

Suryani, "Sistem Perbankan Islam di Indonesia", Jurnal Ekonomi Islam, Voll. 3 No.1, STAIN Malikussaleh, Lhokseumawe, Juli. 2012.

Utari, Herlina. "Pengaruh Inflasi, Kurs, Bi Rate Terhadap Nilai Aktiva Bersih (NAB) Reksadana Syariah di Indonesia Tahun 2010 - 2018”. Jurnal Ekonomi, Institut Agama Islam Negri Tulungagung, Tulungagung, Oktober 2017. 